\title{
Correction: Transcatheter mitral valve repair: an overview of current and future devices
}

De Backer O, Wong I, Taramasso M, et al. Transcatheter mitral valve repair: an overview of current and future devices. Open Heart 2021;8:e001564. doi: 10.1136/ openhrt-2020-001564

Since the publication of this article, the authors have noticed that in the caption of Figure 8, the system name was incorrect in two instances. 'NeoChord' has been corrected to 'HARPOON'.

Open access This is an open access article distributed in accordance with the Creative Commons Attribution Non Commercial (CC BY-NC 4.0) license, which permits others to distribute, remix, adapt, build upon this work non-commercially, and license their derivative works on different terms, provided the original work is properly cited, appropriate credit is given, any changes made indicated, and the use is non-commercial. See: http://creativecommons.org/licenses/by-nc/4.0/.

(C) Author(s) (or their employer(s)) 2021. Re-use permitted under CC BY-NC. No commercial re-use. See rights and permissions. Published by BMJ.

Open Heart 2021;8:e001564corr1. doi:10.1136/openhrt-2020-001564corr1

A) Check for updates 